\title{
Chemical Characterization of Coal Fly Ash Samples by ICP-AES and ICP-MS With Focus on Trace Level Toxic Elements
}

\author{
V. Padmasubashini* and G. Chakrapani \\ Chemistry Group, \\ Atomic Minerals Directorate for Exploration \& Research, \\ Begumpet, Hyderabad 500016, India
}

\section{INTRODUCTION}

Thermal power stations produce enormous quantities of coal ash as a by-product of combustion. Coal ash comes in two forms, fly ash and bottom ash. Fly ash produced from the burning of pulverized coal in a coal-fired boiler is a fine-grained, powdery particulate material that is carried off in the flue gas. It is usually collected by means of electrostatic precipitators, bag houses, or mechanical collection devices such as cyclones. Bottom ash on the other hand is the material dropped from the grate in the furnace (1). Fly ash productionin India was around 130 million tonnes in 2010-11 from about 70 thermal power plants (2) and is expected to increase further in subsequent years. Coal-based thermal power plants all over the world face serious problems of handling and disposal of the ash produced. Safe disposal of the ash without adversely affecting the environment is a major concern. Further, large storage areas are also required for dumping fly ash in ash ponds and landfills. If not managed well, the fine particles of fly ash owing to its weightlessness can become airborne and pose a health hazard. Hence, attempts are being made to utilize the ash rather than dispose it (3).

The extent and nature of the environmental impact that may arise out of the use or disposal of fly ash depends mainly on its chemical composition, particle size, etc. Fly ash contains several potentially toxic elements $(2,4,5)$ such as As,

${ }^{*}$ Corresponding author.

:E-mail: padmasubasbini@gmail.com

E-mail: padmasubashini.amd@gov.in
ABSTRACT
Coal fly ash contains several trace elements some of which are toxic such as $\mathrm{As}, \mathrm{Cr}, \mathrm{Pb}$, etc Coal ash also contains relatively high amounts of rare earth ele- ments whose recovery from coal ash could be an alternate source for their supply. Although ura- nium and thorium are less chemi- cally toxic than other constituent elements such as arsenic, ques- tions have been raised concern- ing the possible risk from radiation. Hence, the concentration levels of all of these trace toxic elements in fly ash samples have to be assessed to determine whether the ash is hazardous or not, and also to decide the place and method of its disposal or re- utilization. In this study, multi- elemental analysis of some coal ash samples originating from two thermal power plants in southern India has been carried out, employ- ing inductively coupled plasma atomic emission spectrometry (ICP-AES) and inductively cou- pled plasma mass spectrometry (ICP-MS), with the focus on some trace toxic elements. The meth- ods employed were validated by analayzing international certified fly ash reference materials. The concentrations of trace-toxic ele- ments in the samples analyzed were: $20-82 \mu \mathrm{g} / \mathrm{g}$ for As, 45-281 $\mu \mathrm{g} / \mathrm{g}$ for $\mathrm{Cr}, 31-607 \mu \mathrm{g} / \mathrm{g}$ for $\mathrm{Ba}$, 21- $865 \mu \mathrm{g} / \mathrm{g}$ for $\mathrm{Sr}, 8-39 \mu \mathrm{g} / \mathrm{g}$ for $\mathrm{Ge},<5-80 \mu \mathrm{g} / \mathrm{g}$ for $\mathrm{Ga},<5-100$ $\mu \mathrm{g} / \mathrm{g}$ for $\mathrm{Cu}, 19-50 \mu \mathrm{g} / \mathrm{g}$ for $\mathrm{Co}$, $58-258 \mu \mathrm{g} / \mathrm{g}$ for $\mathrm{Ni}, 8-73 \mu \mathrm{g} / \mathrm{g}$ for $\mathrm{Pb}$, 44-260 $\mu \mathrm{g} / \mathrm{g}$ for $\mathrm{Zn}, 0.6-8.6$ $\mu \mathrm{g} / \mathrm{g}$ for $\mathrm{U}, 1-30 \mu \mathrm{g} / \mathrm{g}$ for $\mathrm{Th}$, 6-196 $\mu \mathrm{g} / \mathrm{g}$ for $\mathrm{La}, 14-528 \mu \mathrm{g} / \mathrm{g}$ for Ce, $5-196 \mu \mathrm{g} / \mathrm{g}$ for Y. These results were compared with trace-toxic element concentra- tions in coal ash samples as reported in the literature.

$\mathrm{Cr}, \mathrm{Pb}$, etc. Due to the minute particle size, several potentially toxic elements present in the fly ash get leached out of the ash ponds and contaminate the soil, surface and groundwater. These heavy metals have been known to limit the survival and growth of plants and micro-organisms $(4,5)$. Hence, the concentration levels of these trace metals play a role in the classification of the ash as hazardous and how and where to dispose it. Coal ash is also a potential source of rare earth elements (REEs) present in relatively high amounts. These are industrially important elements whose recovery from coal ash could be an alternate source for their supply (6). Fly ash also contains significant amounts of germanium (Ge) which is an important material in the semi-conductor industry. Studies on the recovery of germanium from fly ash have also been reported (7). But there is very limited data available in the literature on the heavy metal content of fly ash collected from different thermal stations. Baba et al. (8) and Karayagit et al. (9) reported the chemical composition of fly ash from power plants in eastern and western Turkey. Fytianos et al. (10) reported trace element data of fly ash from Greece and Llorens et al. (11) reported trace metal data of ash from Spanish thermal power stations. Zelinski and co-workers (12) published work on fly ash originating from Alabama in the USA. Zicheng Peng and co-workers (13) reported the chemical composition of fly ash from China. There have also been a few papers published on fly ash from India. Praharaj et al. (4) studied the leachability and chemical composition of fly ash 
from thermal plants in Orissa, India, while Sushil et al. (2) have studied the heavy metal content and disposal methods at three thermal power plants in northern India. Sivakumar and Datta (14) published a review on groundwater pollution occurring around ash ponds which also contained data on some toxic element contents in fly ash obtained from Indian power plants. In the present work, the authors are reporting the trace metal composition of fly ash samples obtained from two thermal power stations in southern India.

Different analytical methodologies employing a gamut of instrumental techniques have been utilized for chemical characterization of fly ash. Atomic absorption spectrometry, spark source-mass spectrometry, X-ray fluorescence and instrumental neutron activation analysis are some of the techniques used in the analysis of coal products (16). Amongst all, inductively coupled plasma atomic emission spectrometry (ICP-AES) and inductively coupled plasma mass spectrometry (ICP-MS) are presently the most attractive techniques due to the rapid, accurate, precise and highly sensitive multi-element determination and resulting in relative freedom from chemical interferences.

Different sample dissolution procedures have been reported in the literature for chemical characterization of fly ash samples. The choice has to be made between an acid decomposition and a fusion route. Some workers recommend the use of closed PTFE bombs to achieve complete dissolution of the samples without loss of volatiles, whereas some others have advocated the use of a microwave dissolution technique. Karayagit and Gayar (9) reported the complete characterization of fly ash samples from a thermal power plant in eastern Turkey by ICP-MS after dissolving the fly ash samples in a mixture of hydro- fluoric acid and aqua regia. Sushil and Batra (2) analyzed fly ash samples from three thermal power stations in northern India by AAS after dissolving in a mixture of $\mathrm{HF}$ and nitric acid. Nham (15) has described a method for multi-element ICP-AES determination in fly ash samples after sample dissolution in HF and aqua regia with boric acid as the complexant. Nadkarni (16) reported the multi-element determination of fly ash samples using Parr acid bomb dissolution after ashing the sample in a muffle furnace. Later, the same author also reported a microwave oven-based rapid dissolution technique for multi-element analysis of fly ash samples and determined 25 elements by ICP-AES (17). Attili and Daugherty (18) carried out trace metal analysis of fly ash by ICP-AES using the microwave oven dissolution method. Riley and Godbeer (19) described a method for the analysis of whole coal samples using an ultrasonic technique and the concentrations of the elements (Al, Ca, Fe, K, Mg, Mn, Na, P, $\mathrm{Si}$, and $\mathrm{Ti}$ ) were determined by ICPAES. Bettinelli et al. (20) compared different decomposition procedures for analysis of fly ash samples by ICP-AES. The determination of Ga, $\mathrm{Ge}, \mathrm{As}, \mathrm{Se}, \mathrm{Sb}, \mathrm{Cd}, \mathrm{Hg}$, $\mathrm{Tl}$, and $\mathrm{Pb}$ in fly ash samples by slurry sampling coupled to electro-thermal vaporization ICP-MS determination has also been reported $(21,22)$.

In the present work, multi-element analysis of fly ash and bottom ash samples collected from two thermal power stations in southern India has been carried out using ICP-AES and ICP-MS and employing appropriate sample dissolution techniques. The accuracy of the method employed was ascertained by analysis of certified reference materials. The values of trace toxic elements obtained were also compared with values reported in the literature for similar types of samples.

\section{EXPERIMENTAL}

\section{Instrumentation}

A model Platform XS ICP-MS (Micromass Ltd., U.K) was used to determine As, Ge, La, Ce, Y, U, and Th, while a model Ultima-2 ICP-AES (Jobin Yvon Ltd., France) was used to determine the other elements. The instrumental parameters are listed in Tables I, II, and III.

\section{Stock Standard Solutions}

Plasma standard stock solutions ( $1 \mathrm{mg} / \mathrm{mL}$ ) were procured from Alfa Aeser Pvt., Ltd. (Johnson Matthey) for all elements determined, except uranium and thorium. Uranium stock standard solution $(1 \mathrm{mg} / \mathrm{mL}$ ) was prepared from uranyl nitrate (AR grade) and thorium from thorium nitrate salt (AR grade). Working standards were prepared by appropriate dilutions.

\section{Reagents}

All reagents used were of AR grade. Analytical grade acids which were further purified by sub-boiling and ultrapure type- 1 water were used for sample dissolution and dilutions.

\section{Sample Collection}

The samples used in this study were collected from thermal power stations located in Kothagudem in the Telangana state and Neyveli in the Tamil Nadu state of India.

\section{ANALYTICAL METHODOLOGY}

\section{Procedure 1}

A 0.5-g dry sample was placed into a platinum dish and ashed in a muffle furnace at $500{ }^{\circ} \mathrm{C}$ for one hour. To the residue obtained after ignition, $1 \mathrm{~mL}$ of sulphuric acid $(18 \mathrm{~N}), 5 \mathrm{~mL}$ of $40 \%(\mathrm{v} / \mathrm{v}) \mathrm{HF}$, and $2 \mathrm{~mL}$ of $15 \mathrm{M}$ nitric acid were added and evaporated to dryness on a steam water bath. The treatment was repeated again with $3 \mathrm{~mL}$ of $40 \%(\mathrm{v} / \mathrm{v}) \mathrm{HF}$ and $2 \mathrm{~mL}$ of $15 \mathrm{M}$ 
nitric acid. The residue was then dissolved in $3 \mathrm{~mL}$ of $15 \mathrm{M}$ nitric acid and evaporated to dryness. The process was repeated twice and the final solution was filtered into a 50-mL standard flask using Whatman 540 filter paper, then made up to volume and maintaining an acidity of $3 \%(\mathrm{v} / \mathrm{v})$ of $15 \mathrm{M}$ nitric acid. After appropriate dilution, this sample solution was used for ICP-MS analysis of arsenic and germanium. The process blanks were prepared similarly without the samples.

\section{Procedure 2}

A 0.5-g dry sample was placed into a platinum dish and ashed in a muffle furnace at $500{ }^{\circ} \mathrm{C}$ for one hour. The residue obtained after ignition was dissolved in $5 \mathrm{~mL}$ of $40 \%(\mathrm{v} / \mathrm{v}) \mathrm{HF}$ and $2 \mathrm{~mL}$ of $15 \mathrm{M}$ nitric acid and evaporated to dryness on a hot plate. The treatment was repeated again with $3 \mathrm{~mL}$ of $40 \%(\mathrm{v} / \mathrm{v})$ and $2 \mathrm{~mL}$ of $15 \mathrm{M}$ nitric acid. The residue was then dissolved in $3 \mathrm{~mL}$ of $15 \mathrm{M}$ nitric acid and evaporated to dryness. The nitration process was repeated twice and the final solution was filtered with a Whatman 540 filter

TABLE I

Instrumental Parameters of ICP-AES

\begin{tabular}{lr} 
Mounting & Czerny-Turner \\
Focal Length & $1 \mathrm{~m}$ \\
Grating & 4320 grooves $/ \mathrm{m}$ \\
& and 2400 grooves $/ \mathrm{m}$ \\
Order of Measurement & $1 \mathrm{st}$ \\
1 st Order Resolution & 0.005 \\
Type of Generator & Solid state \\
Observation & Radial View \\
Frequency of Generator & $40.68 \mathrm{MHz}$ \\
Power & $1000 \mathrm{~W}$ \\
Plasma Gas Flow Rate & $12 \mathrm{~L} / \mathrm{min}$ \\
Sheath Gas Flow Rate & $0.2 \mathrm{~L} / \mathrm{min}$ \\
Nebulizer Gas Flow Rate & $0.8 \mathrm{~L} / \mathrm{min}$ \\
Nebulizer Type & Meinhard \\
Type of Spray Chamber & Cyclonic \\
Injector Tube Diameter & $1.8 \mathrm{~mm}$ \\
\hline
\end{tabular}

paper into a 50-mL standard flask maintaining an acidity of 3\% (v/v) $15 \mathrm{M}$ nitric acid. If any residue remained at this stage, the filter paper with the residue was taken into a platinum dish, ashed at $600{ }^{\circ} \mathrm{C}$, and the ash dissolved using the

\section{TABLE II}

Wavelengths Used for ICP-AES Determination

\begin{tabular}{|c|c|}
\hline $\mathrm{Ba} \quad 230.424 \mathrm{~nm}$ & Al $309.284 \mathrm{~nm}$ \\
\hline Co $228.616 \mathrm{~nm}$ & Ca $393.365 \mathrm{~nm}$ \\
\hline $\mathrm{Cr} \quad 267.716 \mathrm{~nm}$ & $\operatorname{Mg} 279.553 \mathrm{~nm}$ \\
\hline $\mathrm{Cu} 324.754 \mathrm{~nm}$ & Fe $259.940 \mathrm{~nm}$ \\
\hline Ga $294.364 \mathrm{~nm}$ & $\operatorname{Mn} 257.553 \mathrm{~nm}$ \\
\hline $\mathrm{Ni} 231.604 \mathrm{~nm}$ & Ti $334.941 \mathrm{~nm}$ \\
\hline $\mathrm{Pb} 220.353 \mathrm{~nm}$ & Si $212.412 \mathrm{~nm}$ \\
\hline $\mathrm{Sr} \quad 407.771 \mathrm{~nm}$ & P $\quad 213.618 \mathrm{~nm}$ \\
\hline $\mathrm{Zn} 213.856 \mathrm{~nm}$ & $\mathrm{Na} 589.995 \mathrm{~nm}$ \\
\hline Th $401.913 \mathrm{~nm}$ & K $766.490 \mathrm{~nm}$ \\
\hline La $333.749 \mathrm{~nm}$ & Y $371.029 \mathrm{~nm}$ \\
\hline Ce $418.660 \mathrm{~nm}$ & \\
\hline
\end{tabular}

same process as described earlier. The final solution obtained was added to the first filtrate taken into a 50-mL standard flask and made up to volume maintaining $3 \%(\mathrm{v} / \mathrm{v})$ of $15 \mathrm{M}$ nitric acid. This sample solution was used for ICP-AES analysis of the major and minor constituents. The trace metals were determined after appropriate dilution by ICPMS. Process blanks were prepared similarly without the samples.

\section{RESULTS AND DISCUSSION}

Eight samples, four of lignite origin (from the Neyveli thermal power station in Tamilnadu, India) and four of sub-bituminous origin (from the Kothagudem thermal power station in Telangana, India), were analyzed after sample dissolution. Of the eight samples analyzed, four were fly ash samples and four were bottom ash samples. The authors first determined the major

TABLE III

Instrumental Parameters of ICP-MS

\begin{tabular}{lr}
\hline \multicolumn{1}{l}{ Analyzer } \\
Cone Lens Voltage \\
Hexapole Exit Lens Voltage & $-390 \mathrm{~V}$ \\
Hexapole Bias & $-380 \mathrm{~V}$ \\
Detector & $0.0 \mathrm{~V}$ \\
Photo Multiplier Voltage & \\
Pressures & \\
Analyzer Vacuum & $10^{-5} \mathrm{mbar}$ \\
Torch & \\
Forward Power & $1250 \mathrm{~W}$ \\
Gas & $13.5 \mathrm{~L} / \mathrm{min}$ \\
Plasma - Cool Gas & $1.3 \mathrm{~L} / \mathrm{min}$ \\
Plasma - Intermediate Gas & $0.8 \mathrm{~L} / \mathrm{min}$ \\
Plasma - Nebulizer Gas & $8.0 \mathrm{~mL} / \mathrm{min}$ \\
Hexapole Gas - Helium & $4.0 \mathrm{~mL} / \mathrm{min}$ \\
Hexapole Gas - Hydrogen & $1 \mathrm{~mL} / \mathrm{min}$ \\
Solution Uptake Rate (Pumped) & $3-4{ }^{\circ} \mathrm{C}$ \\
Spray Chamber Temperature & Ni-Cu, 1.1 mm Orifice Diameter \\
Sampler Cone & $\mathrm{Ni}, 0.7 \mathrm{~mm}$ Orifice Diameter \\
Skimmer Cone & Peak Hopping (SIR) \\
Mode & $200 \mathrm{~ms}$ \\
Dwell Time & \\
\hline &
\end{tabular}


and minor constituent elements in these samples using ICP-AES to ascertain their matrix composition. The trace toxic elements of these samples (Ge, Ga, Ba, Sr, Cr, Cu, Co, $\mathrm{Ni}, \mathrm{Pb}, \mathrm{Zn}$ ), the REEs (La, Ce and $\mathrm{Y}$ ), and $\mathrm{U}$ and Th were then quantified using ICP-AES and ICP-MS. Recovery studies, especially for the elements As and Ge, were carried out using spiked samples. The analytical methodology used in the present work was validated by application to international certified fly ash reference materials SRM 2689 Coal Fly Ash and SRM 1633a Coal fly Ash, both obtained from The National Institute of Standards and Technology, Gaithersburg, MD, USA. Wherever feasible, the values obtained were checked by analyzing the solutions using alternate techniques. The \% RSD for all of the estimated elements varied from 3 to $10 \%$ at the $\mu \mathrm{g} / \mathrm{g}$ level of concentration.

\section{Selection of Sample Dissolution Method and Recovery Studies}

Essentially, the choice was made between an acid decomposition and a fusion route for dissolution of the coal ash samples (15). Since the present study involved determination of some volatile toxic elements which could be lost during high temperature fusions, acid dissolution procedures were preferred over fusion procedures. Further, an ashing step at high temperatures prior to the acid dissolution step was also carried out to remove the carbonaceous matter from the samples. This ashing step was essential to achieve quantitative recoveries (16). Recovery studies using spiked samples were carried out to check whether any loss of arsenic and germanium occurred during ashing. The recoveries were found to be quantitative $(>95 \%)$ proving that there was no significant loss of arsenic and germanium when ashed at $600{ }^{\circ} \mathrm{C}$.
Different sample dissolution procedures were adopted for different elements in this study. Though some workers reported use of a single sample solution for the determination of a suite of elements, it was observed by the present authors that it is not feasible to achieve complete characterization of the ash samples using a single solution since fly ash is a complex matrix composed of both silica and organic matter. For the complete quantitative recovery of elements from the silicate matrix, hydrofluoric acid was invariably considered to be employed. Though some workers advocate the use of aqua regia for the recovery of trace elements, aqua regia or hydrochloric acid was not used by the authors since the presence of chloride leads to several problems. The chloride ion causes volatilization of Ge as chloride during sample digestion (24). Hence, nitric acid, which is an oxidant that stabilizes tetravalent Ge, was preferred. Problems are also encountered by the chloride in the ICP-MS detection of As due to the presence of $\mathrm{ArCl}^{+}$(24). Hence, a chloride-free route for sample decomposition was used in the present work. Previous studies stated the volatilization of As(III) and Ge(IV) fluorides from non-oxidizing media of hydrofluoric acid (23). Hence, the authors adopted a slightly variant sample dissolution procedure for the determination of arsenic and germanium wherein lower temperatures (using steam water baths) were employed and a few drops of $18 \mathrm{~N}$ sulphuric acid added to a mineral acid mixture of hydrofluoric acid and nitric acid to prevent volatilization losses during sample decomposition. The presence of sulphate did not pose a problem in the determination of arsenic and germanium by ICP-MS, unlike in GF-AAS where it causes signal suppression (25). For other trace elements, a mineral acid mixture of hydrofluoric acid and nitric acid was used for the sample decomposition at a higher temperature using an electric hot plate to achieve complete sample dissolution and quantitative recoveries of the analytes.

\section{Determination of Major and Minor Constituents}

The chemical composition of coal ash depends on location and the type of the coal used as well as the combustion conditions and the efficiency of air pollution control devices installed in the thermal power stations. Table IV lists the results obtained for the major and minor constituents of fly ash and bottom ash samples analyzed in lignite coal ash and sub-bituminous coal ash. The values obtained agreed well with the normal range of chemical composition reported for different types of coal ash in the literature $(3,12)$. The calcium in fly ash samples derived from lignite coal is usually much higher than from sub-bituminous type of coal. The fly ash samples from lignite coal contained 7.71 and $12.40 \%$ of calcium, whereas the one from the sub-bituminous coal contained 1.02 and $0.40 \%$ of calcium. Aluminum, to the contrary was higher in fly ash obtained from sub-bituminous coal (15.82 and $16.54 \%)$ than in the ash obtained from lignite type of coal (7.04 and 9.79\%). The carbon content was also higher in the ash samples obtained from lignite than those obtained from subbituminous coal.

\section{Determination of Trace Toxic Constituents}

The authors determined the trace toxic elements of $\mathrm{Ga}, \mathrm{Ba}, \mathrm{Sr}$, $\mathrm{Cr}, \mathrm{Cu}, \mathrm{Co}, \mathrm{Ni}, \mathrm{Pb}$, and $\mathrm{Zn}$ and the results obtained are listed in Table V. The significant levels of the above elements were detected for all samples.

\section{Determination of As and Ge}

Arsenic is reportedly found in high concentrations in coal fly ash. 


\section{Atomic Spectroscopy \\ Vol. 37(6), Nov./Dec. 2016}

TABLE IV

Concentration of Major/Minor Elements in Coal Ash Samples

\begin{tabular}{|c|c|c|c|c|c|c|c|c|}
\hline & \multicolumn{4}{|c|}{ Lignitic Coal Ash' } & \multicolumn{4}{|c|}{ Sub-bituminous Coal Ash ${ }^{\mathrm{d}}$} \\
\hline Sample No. & AMD 1 & AMD 2 & AMD 3 & AMD 4 & AMD 5 & AMD 6 & AMD 7 & AMD 8 \\
\hline Sample Type & Fly Ash & Fly Ash & Bottom Ash & Bottom Ash & Fly Ash & Fly Ash & Bottom Ash & Bottom Ash \\
\hline Si $[\% g / g]^{a}$ & 26.2 & 19.3 & 24.3 & 25.6 & 27.4 & 27.7 & 29.2 & 30.8 \\
\hline $\operatorname{Ti}[\% g / g]^{a}$ & 0.73 & 0.72 & 0.18 & 0.08 & 0.78 & 0.61 & 0.72 & 0.52 \\
\hline $\mathrm{Al}[\% \mathrm{~g} / \mathrm{g}]^{\mathrm{a}}$ & 7.04 & 9.79 & 0.79 & 0.53 & 15.82 & 16.54 & 13.65 & 11.90 \\
\hline $\mathrm{Fe}[\% \mathrm{~g} / \mathrm{g}]^{\mathrm{a}}$ & 7.41 & 6.99 & 19.23 & 23.43 & 2.87 & 3.08 & 4.33 & 3.85 \\
\hline $\operatorname{Mg}[\% \mathrm{~g} / \mathrm{g}]^{\mathrm{a}}$ & 1.80 & 3.17 & 0.14 & 0.07 & 0.49 & 0.43 & 0.36 & 0.33 \\
\hline $\mathrm{Ca}[\% \mathrm{~g} / \mathrm{g}]^{\mathrm{a}}$ & 7.71 & 12.40 & 0.54 & 0.23 & 1.02 & 0.40 & 0.78 & 0.32 \\
\hline $\operatorname{Mn}[\% \mathrm{~g} / \mathrm{g}]^{\mathrm{a}}$ & $<0.01$ & $<0.01$ & $<0.01$ & $<0.01$ & 0.03 & 0.03 & 0.05 & 0.05 \\
\hline $\mathrm{Na}[\% \mathrm{~g} / \mathrm{g}]^{\mathrm{a}}$ & 0.25 & 0.49 & 0.02 & 0.01 & 0.14 & 0.16 & 0.13 & 0.10 \\
\hline $\mathrm{K}[\% \mathrm{~g} / \mathrm{g}]^{\mathrm{a}}$ & 0.03 & 0.04 & $<0.01$ & $<0.01$ & 0.91 & 0.90 & 0.83 & 0.90 \\
\hline $\mathrm{P}[\% \mathrm{~g} / \mathrm{g}]^{\mathrm{a}}$ & 0.01 & 0.01 & $<0.01$ & $<0.01$ & 0.07 & 0.08 & 0.11 & 0.04 \\
\hline $\mathrm{C}^{\mathrm{b}}[\% \mathrm{~g} / \mathrm{g}]^{\mathrm{a}}$ & 2.76 & 2.95 & 7.25 & 3.18 & 0.64 & 0.07 & 0.16 & 1.50 \\
\hline
\end{tabular}

${ }^{\text {a }}$ Values obtained are average of three replicate measurements with RSD ranging from 3-5\%.

${ }^{b}$ Model LiquiTOC II carbon analyzer instrument (Elementar, Germany) was used for total carbon determination.

${ }^{\mathrm{c}}$ From Neyveli plant.

${ }^{\mathrm{d}}$ From Kothagudem plant.

TABLE V Concentration of Trace Toxic Elements in Coal Ash Samples

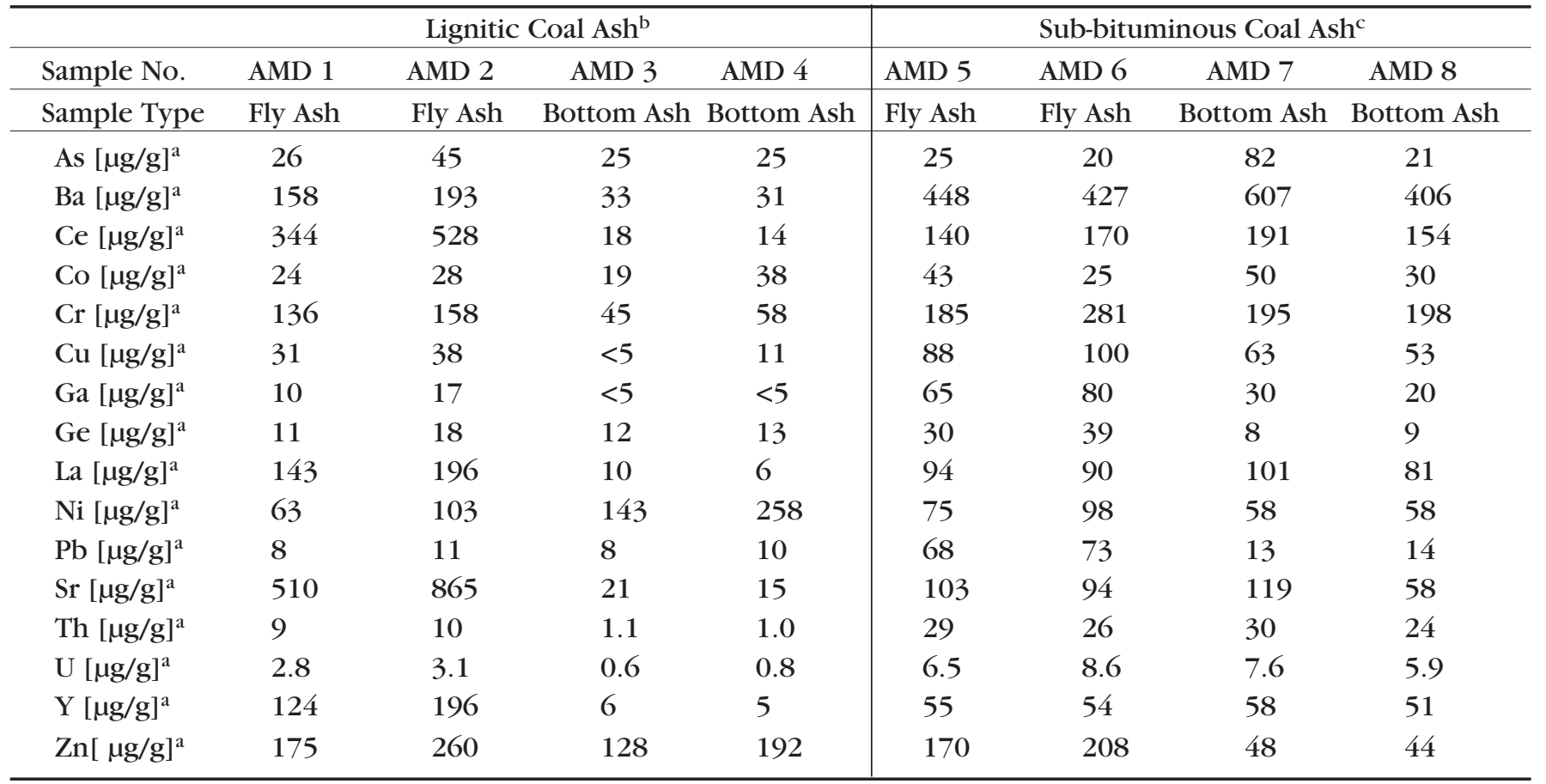

${ }^{a}$ Values obtained are average of three replicate measurements with RSD ranging from 5-10\%.

${ }^{\mathrm{b}}$ From Neyveli plant.

${ }^{\mathrm{c}}$ From Kothagudem plant. 
Arsenic usually has an affinity to sulphide minerals and this association is well documented for some coals. In contrast, the mode of occurrence is less known and less understood in fly ash. Probably calcium arsenate is a host for arsenic in fly ash (12). The arsenic concentrations obtained in the present study (Table V) were in the range of $20-82 \mu \mathrm{g} / \mathrm{g}$. Germanium occurs in relatively high concentrations in a number of coal basins and gets concentrated in fly ashes whose germanium concentration can be 10 times higher than in coal. Higher germanium concentrations were obtained in sub-bituminous fly ash (30 and $39 \mu \mathrm{g} / \mathrm{g}$ ) when compared to the lignitic fly ash (11 and 18 $\mu \mathrm{g} / \mathrm{g})$. The sample solutions were also analyzed for arsenic and germanium by hydride generation atomic absorption spectrometry (HG-AAS) technique. The values obtained by ICP-MS compared well with those obtained by HG-AAS, thereby confirming the accuracy of the present ICP-MS methodology.

\section{Determination of $\mathbf{U}$ and $\mathbf{T h}$}

Uranium and thorium concentrations were higher in the sub-bituminous ash than in the lignitic ash samples (Table V). The lignitic ash samples were found to have uranium from $1-3 \mu \mathrm{g} / \mathrm{g}$, whereas the sub-bituminous ash samples contained $6-9 \mu \mathrm{g} / \mathrm{g}$ of uranium. The thorium concentrations in the ash samples were higher than the uranium levels. Thorium was found to be in the range of $9-10 \mu \mathrm{g} / \mathrm{g}$ in the lignitic fly ash and in the range of $26-29 \mu \mathrm{g} / \mathrm{g}$ in the sub-bituminous fly ash samples. The solutions were also analyzed by fluorimetry for uranium and by ICP-AES for thorium. The values compared well thereby confirming the accuracy of the present ICP-MS methodology.

\section{Determination of Rare Earth Elements (La, Ce, and Y)}

Significantly higher levels of rare earth elements (lanthanum, cerium. and yttrium) were obtained in the fly ash samples in comparison to the bottom ash samples in case of lignitic samples. However, in the case of sub-bituminous samples, significantly high amounts of rare earths were obtained in both the fly ash and bottom ash samples. The La, Ce. and Y values obtained compared well with those obtained by ICP-OES.

\section{Statistical Analysis of Trace Toxic Element Concentrations in Fly Ash Samples}

The correlation coefficients were calculated for the trace toxic element concentrations in the four fly ash samples analyzed (AMD-1, 2, 5, and 6) and are listed in Table VI. Good correlation was found among the three rare earth elements of La$\mathrm{Ce}, \mathrm{La}-\mathrm{Y}$ and Ce-Y. Good correlation was also found between arsenic and the rare earth elements (La-As, Ce-As, and Y-As) as well as between As-Zn. Good correlation was obtained for $\mathrm{U}$ and Th with $\mathrm{Pb}$ and $\mathrm{Ba}$ (U-Th, U-Pb, and Th- $\mathrm{Pb}$, U$\mathrm{Ba}$, and Th-Ba). Negative correlation coefficients were found for Ba-La, Ba-Ce, Ba-Y, As-U, and As-Th, etc. Chromium had positive correlation with $\mathrm{Ba}, \mathrm{Cu}, \mathrm{Ga}, \mathrm{Ge}, \mathrm{Pb}$, Th, and $\mathrm{U}$ and negative coefficients with As, Ce, La, and Y.

\section{Validation of Methods Employed}

The international certified reference materials of NIST SRM 1633a and NIST SRM 2689 Fly Ash were analyzed by the present methods. The results listed in Tables VII and VIII are in good agreement with the certified/consensus values or information values available in the literature. This proves the accuracy of the results obtained in the present study. Certified or information values are not available in the litera- ture for some elements reported in the present study, especially for NIST SRM 2689. Hence, the values reported in the present work for elements whose values are not yet available can serve as usable values for the above two reference materials.

\section{Comparison of Trace Toxic Ele- ment Concentrations Obtained in This Study vs. With Literature Values}

A comparison of values obtained in the present study with those reported in the literature is listed in Table IX. The arsenic concentrations obtained in the present study were in the range of $20-82 \mu \mathrm{g} / \mathrm{g}$ which is lower than typical arsenic in coal ash samples reported elsewhere (94-225 $\mu \mathrm{g} / \mathrm{g}$ in Turkey and the USA) $(8,9,12)$. Relatively high concentrations of germanium were obtained in sub-bitum- inous fly ash (30-39 $\mu \mathrm{g} / \mathrm{g})$ compared to those reported in Turkey $(6.2 \mu \mathrm{g} / \mathrm{g})(8$, 9). Significant levels of the rare earth elements (lanthanum, cerium, and yttrium) were found in the ash sample which is higher than the typical La, Ce, and Y levels in coal ash samples reported elsewhere (27-53 $\mu \mathrm{g} / \mathrm{g}$ in Turkey and 49-123 $\mu \mathrm{g} / \mathrm{g}$ in Poland $(6,8,9))$. Uranium values are lower $(<10 \mu \mathrm{g} / \mathrm{g}) \mathrm{com}-$ pared to $10-20 \mu \mathrm{g} / \mathrm{g}$ reported elsewhere (12). Lead values in lignitic fly ash are very low (8-11 $\mu \mathrm{g} / \mathrm{g})$, whereas in sub-bituminous fly ash (68-73 $\mu \mathrm{g} / \mathrm{g}$ ) they are comparable to those reported elsewhere (73 $\mu \mathrm{g} / \mathrm{g}$ in the USA) (12).

\section{CONCLUSION}

A chemical characterization of coal ash samples from two thermal power stations in southern India has been carried out using ICP-AES and ICP-MS after appropriate sample dissolution. Various major, minor, and trace toxic constituents were determined and the values obtained were assessed and compared with typical levels of the ele- 


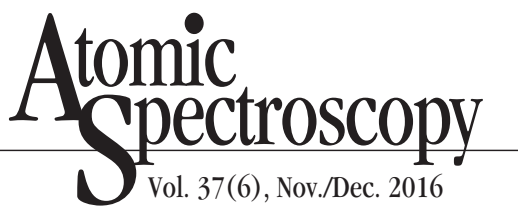

TABLE VI

Correlation Matrix Between Trace Toxic Element Concentrations in Coal Fly Ash Samples

\begin{tabular}{|c|c|c|c|c|c|c|c|c|c|c|c|c|c|c|c|c|}
\hline & As & $\mathrm{Ba}$ & $\mathrm{Ce}$ & Co & $\mathrm{Cr}$ & $\mathrm{Cu}$ & Ga & $\mathrm{Ge}$ & La & $\mathrm{Ni}$ & $\mathrm{Pb}$ & $\mathrm{Sr}$ & $\mathrm{Th}$ & $\mathrm{U}$ & $\mathrm{Y}$ & $\mathrm{Zn}$ \\
\hline As & 1.000 & -0.602 & 0.902 & -0.072 & -0.546 & -0.642 & -0.645 & -0.526 & 0.928 & 0.444 & -0.668 & 0.907 & -0.629 & -0.676 & 0.923 & 0.793 \\
\hline $\mathrm{Ba}$ & -0.602 & 1.000 & -0.864 & 0.584 & 0.751 & 0.980 & 0.973 & 0.927 & -0.852 & 0.159 & 0.992 & -0.877 & 0.997 & 0.932 & -0.854 & -0.337 \\
\hline $\mathrm{Ce}$ & 0.902 & -0.864 & 1.000 & -0.453 & -0.603 & -0.849 & -0.841 & -0.723 & 0.995 & 0.299 & -0.885 & 0.996 & -0.890 & -0.821 & 0.997 & 0.736 \\
\hline Co & -0.072 & 0.584 & -0.453 & 1.000 & -0.078 & 0.414 & 0.381 & 0.282 & -0.363 & -0.197 & 0.480 & -0.400 & 0.624 & 0.250 & -0.386 & -0.364 \\
\hline $\mathrm{Cr}$ & -0.546 & 0.751 & -0.603 & -0.078 & 1.000 & 0.865 & 0.882 & 0.934 & -0.658 & 0.508 & 0.816 & -0.666 & 0.705 & 0.933 & -0.643 & 0.039 \\
\hline $\mathrm{Cu}$ & -0.642 & 0.980 & -0.849 & 0.414 & 0.865 & 1.000 & 0.999 & 0.975 & -0.857 & 0.246 & 0.995 & -0.877 & 0.966 & 0.985 & -0.854 & -0.270 \\
\hline $\mathrm{Ga}$ & -0.645 & 0.973 & -0.841 & 0.381 & 0.882 & 0.999 & 1.000 & 0.981 & -0.853 & 0.263 & 0.992 & -0.872 & 0.956 & 0.990 & -0.849 & -0.255 \\
\hline $\mathrm{Ge}$ & -0.526 & 0.927 & -0.723 & 0.282 & 0.934 & 0.975 & 0.981 & 1.000 & -0.744 & 0.443 & 0.950 & -0.766 & 0.895 & 0.982 & -0.737 & -0.066 \\
\hline $\mathrm{La}$ & 0.928 & -0.852 & 0.995 & -0.363 & -0.658 & -0.857 & -0.853 & -0.744 & 1.000 & 0.263 & -0.885 & 0.999 & -0.872 & -0.846 & 1.000 & 0.710 \\
\hline $\mathrm{Ni}$ & 0.444 & 0.159 & 0.299 & -0.197 & 0.508 & 0.246 & 0.263 & 0.443 & 0.263 & 1.000 & 0.165 & 0.235 & 0.081 & 0.291 & 0.276 & 0.865 \\
\hline $\mathrm{Pb}$ & -0.668 & 0.992 & -0.885 & 0.480 & 0.816 & 0.995 & 0.992 & 0.950 & -0.885 & 0.165 & 1.000 & -0.905 & 0.985 & 0.968 & -0.884 & -0.346 \\
\hline $\mathrm{Sr}$ & 0.907 & -0.877 & 0.996 & -0.400 & -0.666 & -0.877 & -0.872 & -0.766 & 0.999 & 0.235 & -0.905 & 1.000 & -0.896 & -0.860 & 0.999 & 0.690 \\
\hline Th & -0.629 & 0.997 & -0.890 & 0.624 & 0.705 & 0.966 & 0.956 & 0.895 & -0.872 & 0.081 & 0.985 & -0.896 & 1.000 & 0.909 & -0.876 & -0.405 \\
\hline $\mathrm{U}$ & -0.676 & 0.932 & -0.821 & 0.250 & 0.933 & 0.985 & 0.990 & 0.982 & -0.846 & 0.291 & 0.968 & -0.860 & 0.909 & 1.000 & -0.839 & -0.226 \\
\hline $\mathrm{Y}$ & 0.923 & -0.854 & 0.997 & -0.386 & -0.643 & -0.854 & -0.849 & -0.737 & 1.000 & 0.276 & -0.884 & 0.999 & -0.876 & -0.839 & 1.000 & 0.720 \\
\hline $\mathrm{Zn}$ & 0.793 & -0.337 & 0.736 & -0.364 & 0.039 & -0.270 & -0.255 & -0.066 & 0.710 & 0.865 & -0.346 & 0.690 & -0.405 & -0.226 & 0.720 & 1.000 \\
\hline
\end{tabular}

ments reported elsewhere. The analytical methodology used in the present study was validated for intended use by application to international certified fly ash reference materials. The concentrations of trace-toxic elements in the samples analyzed were found to be: 20-82 $\mu \mathrm{g} / \mathrm{g}$ for As, $45-281 \mu \mathrm{g} / \mathrm{g}$ for $\mathrm{Cr}, 31-607 \mu \mathrm{g} / \mathrm{g}$ for Ba, 21- $865 \mu \mathrm{g} / \mathrm{g}$ for $\mathrm{Sr}, 8-39 \mu \mathrm{g} / \mathrm{g}$ for $\mathrm{Ge},<5-80 \mu \mathrm{g} / \mathrm{g}$ for $\mathrm{Ga},<5-100 \mu \mathrm{g} / \mathrm{g}$ for $\mathrm{Cu}, 19-50$ $\mu \mathrm{g} / \mathrm{g}$ for $\mathrm{Co}, 58-258 \mu \mathrm{g} / \mathrm{g}$ for $\mathrm{Ni}$, $8-73 \mu \mathrm{g} / \mathrm{g}$ for $\mathrm{Pb}, 44-260 \mu \mathrm{g} / \mathrm{g}$ for $\mathrm{Zn}, 0.6-8.6 \mu \mathrm{g} / \mathrm{g}$ for $\mathrm{U}, 1-30 \mu \mathrm{g} / \mathrm{g}$ for $\mathrm{Th}, 6-196 \mu \mathrm{g} / \mathrm{g}$ for $\mathrm{La}, 14-528 \mu \mathrm{g} / \mathrm{g}$ for Ce, and 5-196 $\mu \mathrm{g} / \mathrm{g}$ for $\mathrm{Y}$. The analytical data of the heavy metal content of coal ash samples as reported in this paper are highly useful in predicting the environmental impact associated with the recycling or disposal methods currently adopted for coal ash.

\section{ACKNOWLEDGMENT}

The authors thank Dr. A.K. Rai, Director, AMD, for his kind permission to publish this work and also Mr. G. B. Joshi, Additional Director (R\&D), for his encouragement. The authors thank the PMSG and SCR groups of AMD, Hyderabad, for providing the samples.

Received May 11, 2016.

\section{REFERENCES}

1. About coal Ash, retrieved on 4/5/2016 from https://www.acaausa.org/About-Coal-Ash

2. S. Sushil and V.S. Batra, Fuel 85, 2676 (2006).

3. N.S.Pandian, J. Indian Institute of Science 84, 189 (2004).

4. T. Praharaj, M.A.Powell, B.R.Hart and S.Tripathy, Environment International 27(8), 609 (2002).
5. S. Dhadse, Pramila Kumari and L.J.Bhagia, J. Scientific and Industrial Res. 67, 11(2008).

6. W. Franus, M.M. Wiatros-Motyka and M.Wdowin, Environmental Science and Pollution Res. 22, 9464 (2015).

7. F. Arroyo Torralvo and C.FernándezPereira, Minerals Engineering 24, 35 (2011).

8. A. Baba and A.Kaya, J.Environmental Management 73(3), 199 (2004).

9. A.I. Karayagit and R.A. Gayer, International Ash Utilization Symposium, Center of Applied Energy Research, University of Kentucky, USA, Paper-4 (2001). Retrieved on 4/5/2016 from: http://www.flyash.info

10. K. Fytianos, B. Tsaniklidi and E. Voudrias, Environment International 24(4), 477 (1998).

11. J.F. Llorens, J.L. Fernandez-Turiel and X. Querol, Environmental Geology 40(4-5), 409 (2001).

12. R.A. Zelinski, A.L. Foster, G.P. 
TABLE VII

Concentrations of Major/Minor Elements in Certified Fly Ash Reference Materials

\begin{tabular}{lll|ll}
\hline & \multicolumn{2}{c|}{ NIST SRM 2689 } & \multicolumn{2}{c}{ NIST SRM 1633a } \\
\hline & $\begin{array}{c}\text { Present } \\
\text { Value }^{\mathrm{a}}\end{array}$ & $\begin{array}{c}\text { Certified } \\
\text { Value }\end{array}$ & $\begin{array}{c}\text { Present } \\
\text { Value }^{\mathrm{a}}\end{array}$ & $\begin{array}{c}\text { Certified } \\
\text { Value }\end{array}$ \\
\hline $\mathrm{Si}[\% \mathrm{~g} / \mathrm{g}]$ & 24.0 & $24.06 \pm 0.21$ & 23.1 & $22.8 \pm 0.8$ \\
$\mathrm{Ti}[\% \mathrm{~g} / \mathrm{g}]$ & 0.75 & $0.75 \pm 0.01$ & 0.70 & 0.80 \\
$\mathrm{Al}[\% \mathrm{~g} / \mathrm{g}]$ & 12.80 & $12.94 \pm 0.21$ & 14.1 & $14.3 \pm 1.0$ \\
$\mathrm{Fe}[\% \mathrm{~g} / \mathrm{g}]$ & 8.67 & $9.32 \pm 0.06$ & 9.10 & $9.40 \pm 0.1$ \\
$\mathrm{Mg}[\% \mathrm{~g} / \mathrm{g}]$ & 0.59 & $0.61 \pm .05$ & 0.448 & $0.455 \pm 0.01$ \\
$\mathrm{Ca}[\% \mathrm{~g} / \mathrm{g}]$ & 2.05 & $2.18 \pm 0.06$ & 1.01 & $1.11 \pm .01$ \\
$\mathrm{Mn}[\% \mathrm{~g} / \mathrm{g}]$ & 0.026 & $0.030^{\mathrm{b}}$ & 0.017 & 0.019 \\
$\mathrm{Na}[\% \mathrm{~g} / \mathrm{g}]$ & 0.21 & $0.25 \pm 0.03$ & 0.18 & $0.17 \pm 0.01$ \\
$\mathrm{~K}[\% \mathrm{~g} / \mathrm{g}]$ & 2.08 & $2.20 \pm 0.03$ & 1.83 & $1.88 \pm 0.06$ \\
$\mathrm{P}[\% \mathrm{~g} / \mathrm{g}]$ & 0.09 & $0.10 \pm 0.01$ & 0.165 & $0.169 \pm 0.024$ \\
$\mathrm{C}[\% \mathrm{~g} / \mathrm{g}]$ & 1.47 & $\mathrm{NA}^{\mathrm{c}}$ & 2.83 & $\mathrm{NA}^{\mathrm{c}}$ \\
\hline
\end{tabular}

${ }^{a}$ Values obtained are average of three replicate measurements with RSD ranging from $3-5 \%$.

b Information values.

${ }^{\mathrm{c}} \mathrm{NA}=$ Values not available.

${ }^{\mathrm{d}}$ A Model LiquiTOC II carbon analyzer instrument (Elementar, Germany) was used for total carbon determination.

TABLE VIII

Concentrations of Trace Toxic Elements in Certified Fly Ash Reference Materials

\begin{tabular}{lcc|cl}
\hline & \multicolumn{2}{c|}{ NIST SRM 2689 } & \multicolumn{2}{c}{ NIST SRM 1633a } \\
\hline & $\begin{array}{c}\text { Present } \\
\text { Value }^{\mathrm{a}}\end{array}$ & $\begin{array}{c}\text { Certified } \\
\text { Value }\end{array}$ & $\begin{array}{c}\text { Present } \\
\text { Value }^{\mathrm{a}}\end{array}$ & $\begin{array}{c}\text { Certified } \\
\text { Vaue }\end{array}$ \\
\hline $\mathrm{As}[\mu \mathrm{g} / \mathrm{g}]$ & 168 & $200^{\mathrm{b}}$ & 149 & $145 \pm 15$ \\
$\mathrm{Ba}[\mu \mathrm{g} / \mathrm{g}]$ & 725 & $800^{\mathrm{b}}$ & 1260 & 1500 \\
$\mathrm{Ce}[\mu \mathrm{g} / \mathrm{g}]$ & 145 & $\mathrm{NA}^{\mathrm{c}}$ & 155 & 180 \\
$\mathrm{Co}[\mu \mathrm{g} / \mathrm{g}]$ & 43 & $48^{\mathrm{b}}$ & 43 & 46 \\
$\mathrm{Cr}[\mu \mathrm{g} / \mathrm{g}]$ & 175 & $170^{\mathrm{b}}$ & 190 & $196 \pm 6$ \\
$\mathrm{Cu}[\mu \mathrm{g} / \mathrm{g}]$ & 136 & $\mathrm{NA}^{\mathrm{c}}$ & 119 & $118 \pm 3$ \\
$\mathrm{Ga}[\mu \mathrm{g} / \mathrm{g}]$ & 42 & $\mathrm{NA}^{\mathrm{c}}$ & 48 & 58 \\
$\mathrm{Ge}[\mu \mathrm{g} / \mathrm{g}]$ & 58 & $\mathrm{NA}^{\mathrm{c}}$ & 33 & $33.9 \pm 0.2$ \\
$\mathrm{La}[\mu \mathrm{g} / \mathrm{g}]$ & 63 & $\mathrm{NA}^{\mathrm{c}}$ & 71 & $84 \pm 8$ \\
$\mathrm{Ni}[\mu \mathrm{g} / \mathrm{g}]$ & 118 & $122^{\mathrm{a}}$ & 160 & $127 \pm 4$ \\
$\mathrm{~Pb}[\mu \mathrm{g} / \mathrm{g}]$ & 65 & $52^{\mathrm{b}}$ & 76 & $72.4 \pm 0.4$ \\
$\mathrm{Sr}[\mu \mathrm{g} / \mathrm{g}]$ & 605 & $700^{\mathrm{b}}$ & 770 & $830 \pm 30$ \\
$\mathrm{Th}[\mu \mathrm{g} / \mathrm{g}]$ & 18 & $\mathrm{NA}^{\mathrm{b}}$ & 18 & $24.7 \pm 0.3$ \\
$\mathrm{U}[\mu \mathrm{g} / \mathrm{g}]$ & 22 & $25^{\mathrm{b}}$ & 9 & $10.2 \pm 0.1$ \\
$\mathrm{Y}[\mu \mathrm{g} / \mathrm{g}]$ & 73 & $\mathrm{NA}^{\mathrm{c}}$ & 83 & $82 \pm 6$ \\
$\mathrm{Zn}[\mu \mathrm{g} / \mathrm{g}]$ & 260 & $240^{\mathrm{b}}$ & 228 & $220 \pm 10$ \\
\hline $\mathrm{Va}$ & & &
\end{tabular}

${ }^{a}$ Values obtained are average of three replicate measurements with RSD ranging from $5-10 \%$.

${ }^{\mathrm{b}}$ Information values.

${ }^{\mathrm{c}} \mathrm{NA}=$ Not available.
Meeker, A.E. Koenig and I.K. Brownfield, Fuel 86, 560 (2007).

13. G. Liu, H. Zhang, L. Gao, L. Zheng, Z. Peng, Fuel Processing Technol. 85, 1635 (2004).

14. D.S. Sivakumar and M. Datta, Ash ponds and ash disposal systems, Editor: V.S. Raju, Narosa Publishing House, New Delhi, India, 311 (1996).

15. T.T. Nham , ICP-AES Instruments at work, Analysis of coal fly ash by inductively coupled plasma-emission spectrometry, Varian Australia Pvt. Ltd, Australia, ICP-5 (Sept.1991).

16. R.A. Nadkarni, Anal. Chem. 52, 929 (1980).

17. R.A. Nadkarni, Anal. Chem. 56, 2233 (1984).

18. B.S. Attili and K.E. Daugherty, Symposium on Clean Energy from Waste and Coal: Ash Utilization, Characterization and Other Topics, New York, Symposium Series 36(4) (1991). Retrieved on 4/5/2016 from

https://web.anl.gov/ PCS/ acsfuel/preprint $\% 20$ archive/Files/3 6_4_NEW\%20YORK_0891_1785.pdf

19. K.W. Riley and W.C. Godbeer, Analyst 115, 865 (1990).

20. M. Bettinelli, U. Baroni and N. Pastorelli, J. Anal. At. Spectrom. 2, 485 (1987).

21. J. Ni, C. Liu and S. Jiang, Anal. Chim. Acta 550(1-2), 144 (2005).

22. S.M. Maia, D. Pozebona and A. J. Curtius , J. Anal. At. Spectrom. 18, 330 (2003).

23. S. Bajo, Anal.Chem. 50(4), 649 (1978).

24. C. Wang, S. Jeng and F. Shieh, J. Anal. At. Spectrom. 12, 61 (1997).

25. S. Fengi, B. Zhou, L. Zeng and R. Cheni, Chinese Chemical Lett. 10(4), 333 (1999). 


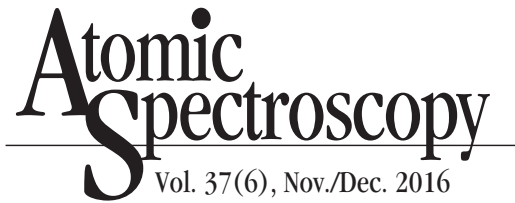

TABLE IX

Comparison of Trace Toxic Element Concentrations Obtained in This Study With Those Reported in the Literature for Coal Fly Ash Samples

\begin{tabular}{|c|c|c|c|c|c|c|c|c|c|c|}
\hline \multirow[t]{2}{*}{ Elements } & \multicolumn{5}{|c|}{ Power Stations Outside India } & \multicolumn{5}{|c|}{ Indian Power Stations } \\
\hline & $\begin{array}{c}\text { Turkey } \\
(8,9)\end{array}$ & $\begin{array}{l}\text { Poland } \\
\text { (6) }\end{array}$ & $\begin{array}{l}\text { Greece } \\
(10)\end{array}$ & $\begin{array}{l}\text { U.S.A } \\
\text { (12) }\end{array}$ & $\begin{array}{l}\text { Spain } \\
\text { (11) }\end{array}$ & $\begin{array}{l}\text { Orissa } \\
\text { (2) }\end{array}$ & $\begin{array}{l}\text { NCR, } \\
\text { New } \\
\text { Delhi } \\
(2)\end{array}$ & $\begin{array}{l}\text { Indian } \\
\text { Average } \\
\text { (2) }\end{array}$ & $\begin{array}{l}\text { This } \\
\text { Site1 } \\
\text { Neyveli }\end{array}$ & $\begin{array}{l}\text { Study } \\
\text { Site } 2 \\
\text { Kothaguyam }\end{array}$ \\
\hline As, $\mu \mathrm{g} / \mathrm{g}$ & 94,143 & & & 22 & & $2.2-4.7$ & & & 26,45 & 25,20 \\
\hline $\mathrm{Ba}, \mu \mathrm{g} / \mathrm{g}$ & 607,717 & & & & & $60.2-82.2$ & & & 158,193 & 448,427 \\
\hline $\mathrm{Co}, \mu \mathrm{g} / \mathrm{g}$ & 20,15 & & & 61 & 29.2 & $1.9-3.2$ & $8,18,13$ & 23.6 & 24,28 & 43,25 \\
\hline $\mathrm{Cr}, \mu \mathrm{g} / \mathrm{g}$ & & & $110-160$ & 177 & 134.2 & $8-14$ & $87,90,10343$ & 120 & 136,158 & 185,281 \\
\hline $\mathrm{Cu}, \mu \mathrm{g} / \mathrm{g}$ & 49,45 & & $32-63$ & & 71.8 & $16-18$ & $56,83,58$ & 100 & 31,38 & 88,100 \\
\hline $\mathrm{Ga}, \mu \mathrm{g} / \mathrm{g}$ & 13,16 & & & & & & & & 10,17 & 65,80 \\
\hline $\mathrm{Ge}, \mu \mathrm{g} / \mathrm{g}$ & $6.2,1.2$ & & & & & & & & 11,18 & 30,39 \\
\hline $\mathrm{Ni}, \mu \mathrm{g} / \mathrm{g}$ & & & & 107 & 87.9 & $10-20$ & $28,39,63$ & 150 & 63,103 & 75,98 \\
\hline $\mathrm{Pb}, \mu \mathrm{g} / \mathrm{g}$ & 53,48 & & $123-143$ & 73 & 52 & $6-14$ & $20,34,56$ & 35 & 8,11 & 68,73 \\
\hline $\mathrm{Sr}, \mu \mathrm{g} / \mathrm{g}$ & 416,144 & & & & & & & & 510,865 & 103,94 \\
\hline $\mathrm{Zn}, \mu \mathrm{g} / \mathrm{g}$ & 80,282 & & 59.6 & & 222.3 & $10-14$ & $60,64,1244$ & & 175,260 & 170,208 \\
\hline $\mathrm{Th}, \mu \mathrm{g} / \mathrm{g}$ & $18,9.2$ & & & & & & & & 9,10 & 29,26 \\
\hline $\mathrm{U}, \mu \mathrm{g} / \mathrm{g}$ & $17,8.2$ & & & 15 & & & & & $2.8,3.1$ & $6.5,8.6$ \\
\hline $\mathrm{La}, \mu \mathrm{g} / \mathrm{g}$ & 27,25 & $15.5-62$. & & & & & & & 142,196 & 94,90 \\
\hline $\mathrm{Ce}, \mu \mathrm{g} / \mathrm{g}$ & 53,48 & $30.7-172$ & & & & & & & 344,528 & 140,170 \\
\hline $\mathrm{Y}, \mu \mathrm{g} / \mathrm{g}$ & 17,18 & $17.9-73$. & & & & & & & 124,196 & 55,54 \\
\hline
\end{tabular}

